\title{
Review of Web-Based Learning in TVET: History, Advantages and Disadvantages
}

\author{
Zarina Abd Rashid ${ }^{1}$, Sanisah Kadiman ${ }^{1}$, Zuriawahida Zulkifli ${ }^{1}$, Juliyana Selamat ${ }^{1}$, \\ Mohamad Hisyam Mohd. Hashim ${ }^{2}$
}

${ }^{1}$ Sekolah Menengah Kebangsaan, Tun Ismail, Parit Raja, Batu Pahat, Johor, Malaysia

${ }^{2}$ University Tun Hussein Onn (UTHM), Parit Raja, Batu Pahat, Johor, Malaysia

\section{Email address:}

hb130037@siswa.uthm.edu.my (Z. A. Rashid),hb130036@siswa.uthm.edu.my (S. Kadiman), hb130038@siswa.uthm.edu.my (Z.Zulkifli), hb130034@siswa.uthm.edu.my (J. Selamat),mhisyam@uthm.edu.my (M. H. Mohd. Hashim)

\section{To cite this article:}

Zarina Abd Rashid, Sanisah Kadiman, Zuriawahida Zulkifli, Juliyana Selamat, Mohamad Hisyam Mohd. Hashim. Review of Web-Based Learning in TVET: History, Advantages and Disadvantages. International Journal of Vocational Education and Training Research. Vol. 2, No. 2, 2016, pp. 7-17. doi: 10.11648/j.jivetr.20160202.11

Received: December 22, 2015; Accepted: February 24, 2016; Published: March 31, 2016

\begin{abstract}
With the rapid development of technology, more and more teachers and learners are eager to use technologies such as web based for learning and teaching. Undoubtedly, the use of technology in education has positive and negative effect on learners. This paper provides an overview of the broad information regarding web based learning (WBL). The focus of the review is on definition of WBL and the related terms such as e-learning, website and characteristics of WBL. This paper also review a short history of WBL in four generations according to the usage of web based functionalities. The idea is to show how (i) content and quiz, (2) communication, (3) assessment and (4) game based learning which are referred to as "generations of web based learning". The reader is also given an overview of the usage of WBL in technical and vocational education in Malaysia and also a discussion of advantages and disadvantages of WBL.
\end{abstract}

Keywords: Web Base Learning, Technical and Vocational Education, History, Advantages and Disadvantages

\section{Introduction}

The teaching and learning process have undergone tremendous change due to the advent of internet. With the existence of networking, finding information has become so convenient because the internet functions like a virtual library, providing various types of information the the users [1]. As a result, everyone including teachers and students have access to information conveniently and swiftly. The use of websites has become a very important component in the learning process due to the rapid development of the internet. This is because according to [2], the use of the internet in the teaching and learning (T\&L) process can transform the method of memorising and remembering information to accessing, manipulating and generalising information electronically, which can generate critical and innovative minds, in line with the development of the education world nowadays.

The use of computers and the internet have become a need and longer seen as luxury items fit for only certain people. The
Multimedia Supercoridoor which was initiated since 1997 is seen as early steps to creating informed communities that can master knowledge development. The use of the web as a tool to deliver teaching and learning can create a momentum for teachers to integrate this convenience in their teaching and process [3]. According to [4], the computer, the internet and the web cannot be separated because the computer is seen as a tool while the internet and the web are seen as the software to access information. Teaching content can be uploaded directly to websites and during the learning process, students will interact with the teaching media through the internet without the teacher being present. [5] states that web-based learning application can provide a variety of real examples to students by combining text, music, image, video and animation. The combination of sound and voice through screen touch and mouse movement can create an interesting learning experience.

Findings from a research conducted by [6] state that web-based learning can attract students' attention to learn. This finding is parallel with a finding conducted by [7] and [8]. 
Moreover, [9] found that students enjoyed the ability to reflect on other students' contributions to the asynchronous discussion forum. This was similar to [10], who found that students in her interview study indicated that the asynchronous discussion forum provided an opportunity to express themselves more carefully.

What is asynchronous? According to [11] one of the most widely used affordances of the Internet in WBLEs is asynchronous discussion through means of online discussion forums where students can exchange ideas, discuss issues, and collaboratively search for solutions to problems. Students also can use them to think and construct their own ideas, to compare their ideas with those of other people, and to reflect upon and reexamine their own understanding by reading and responding to peers' and instructors' postings. Therefore, asynchronous text based technology is one of the most widely used tools across educational institutions around the world to support online learning [12].

\section{Definition of Web-based Learning}

\subsection{E-Learning}

E-learning definition is often confused with definitions of other terms like online learning, blended learning, distributed learning, mobile learning, internet-based learning, technology-based learning, computer-based learning, web-based learning and virtual learning [13]. There are those who equate e-learning definition with Learning Management Systems (LMS) like Blackboard, WebCt, Moodle, MyGuru, MyLMs and others [14]. E-learning actually involes technology and pedagogy. The technology refers to computers, CD ROMs, electronic devices and the internet. Meanwhile, pedagogy covers online learning, blended learning, distance learning, face-to-face learning, web-based learning, computer-aided instruction, individual learning, network learning and interactive learning.

\subsection{Website}

[15] describes the meaning of website as a page that has interesting and unique visual presentation involving background graphics, logo, font size, menu button and a combination of colors. Through web pages, information can be accessed simply by clicking the mouse. As a conclusion, a web site is software in a computer that displays news, information and particular materials that can be applied as media for teaching and learning. [16].

\subsection{World Wide Web (www)}

The World Wide Web (WWW) is a system that is able to display multimedia information with a combination of text, image, sound and video video [4]. [15] describes that WWW has made the internet more user friendly when it was able to integrate graphics, text and sound in an easily accessible page.

Through WWW, learning materials can be accessed easily. [17] has identified 3 ways how WWW can be used in the classroom: (i) As a tool to bring the outside world in to the classroom. (ii) As a tool to complement classroom activities, (iii) As a tool to open the classroom to the outside world. Moreover, [18] supports WWW as the core of current internet technology that can supply materials and courses conveniently online, especially long distance learning, information distribution and electronic communication in multimedia form.

\subsection{Web-based Learning (WBL)}

[19] have defined web-based learning as a cognitive learning strategy application in a constructive and collaborative learning environment using web facilities. According to [20], web-based learning is a learning program based on hypermedia that uses characteristics and sources from the web to generate a meaningful and supportive learning environment. [21] Meanwhile states that web-based learning refers to the use of network systems to learn content in order to achieve a certain cognitive level and acquire information search skills based on students' active involvement in using information from WWW links or collaborating with friends and experts to solve learning problems. The three definitions above demonstrate how the use of internet and web technologies that applies information from WWW links can help users access information toward improving knowledge and performance [22].

Web-based learning (WBL) method allows individuals to follow learning sessions openly and freely without adhering timetables or attending classes and at their own paces [23]. The use of WBL can be seen as giving a positive impact to students especially from the motivation aspect and teaching and learning process [24]. This is agreed by [25] who states that learning through WBL allows students to communicate beyond the borders of time and geography.

WBL teaching and learning can be divided into 2 main categories [26] which are main and additional characteristics. The main characteristic is interactivity, containing multimedia elements, open system, allowing online search, independent of distance, time and computer platform used, can be accessed globally, electronic publication, widespread and controlled by students. The additional characteristics of WBL are; ease of use, online support, cost-saving, online assessment and others. This finding is supported by [27] who describe the teachers' efforts to involve students in classroom activities using WBL characteristics and the diverse ability of the web is similar to what is mentioned by [26].

\section{History of WBL}

The origin of the internet began during the Cold War circa 1969 in the United States of America. A network was created to link all the military computers across the US so that in the event of a nuclear war, the American military equipment can still function. Within 15 years of the creation of this network, the connected sites are only military and academic sites. In 1972, there were 40 small networks connected to the ARPAnet. At that time, this network was used to small send text files among users. Now it is known as E-Mail and widely used. In 
the 80 's, these networks were connected commercially. We were able to visit from one network to a different network and by this time the term "internet" was used. The internet is the catalyst to WBL. There are 3 initial generations of web support in practical

\section{1. $1^{\text {st }}$ Generation: Content and Quiz}

According to [28], in this phase, lecturers gave students teaching contents and allow students to learn according to time and place.

- Allowing students to learn independently according to time and place.

- Assess students' interest outside of lecture time

- Assigning case studies as student assignment

- Creating discussion forums where each students can submit essays and obtain lecturer's assessment

- Informing students quiz or examination results

- Obtaining students' feedback at the end of the course

\section{2. $2^{\text {nd }}$ Generation: Communication and Construction}

Communication meant in early stages delivering assignments to the lecturer but later on forming teams, exchanging standpoints and reviewing mutually. After 4 years, there was an improvement in web teaching that focused on communication and construction like: 1. The public's sensitivity toward the didactic effects like the activities carried out in Austrian "Forum Neue Medien" or in university. 2. The establishment communities among web trainers [29]. 3. Organized "train-the-trainers" courses. Among the courses conducted was to train university lecturers to use WebCT and produce materials for on line courses.

\section{3. $3^{\text {rd }}$ Generation: Collaboration and Mutual Assessment}

Based on previous experience describe earlier a web-based negotiation game, "Surfing Global Change" (SGC) has been created and implemented [30]. Statistical analysis has revealed that cognitive levels, writing and discussion skills must be evaluated separately to obtain an overall and complete personality description. Based on the rules in SGC, learners can play roles, share, convey and receive opinions until an agreement is achieved.

\section{4. $4^{\text {th }}$ Generation: Game Based Learning (GBL)}

GBL is a learning method widely used in many countries. [31] defines GBL as an activity conducted voluntarily and fun, separated from the real world, filled with uncertainties and should generate motivation in the learning process. [32] states that GBL refers to the use of video games to support teaching and learning. In his research, [33] has found that GBL can increase motivation, learner traits and knowledge. The gaming industry has constantly developed in tandem with the growth of portable devices like smart phones, tablets and notebooks. Software applications known as apps refers to game applications downloaded from the internet to portable devices like smart phones and tablets [34]. GBL has gained a place in the education world nowadays especially to the android generation. Therefore the construction of learning medium should give emphasis on GBL.

\section{The History of Web-based Learning in Malaysia}

Distance learning in Malaysia started in the 1980's with external degree programs offered by established universities from the United Kingdom, such as the University of London. This was followed by off-campus programs offered by the Universiti Sains Malaysia [35]. The mode of delivery was print-based and most of the tutorials were conducted via face-to-face sessions. On account of the lack of internet availability and accessibility in Malaysia, there was limited usage of WBL during the 1980's. Secondly, there was still a strong preference to the face-to-face conventional learning method.

In the 1990's, public universities faced student enrolment problem. Growing awareness of lifelong learning further led to the increasing demand for higher educational services. This environment prompted tertiary educational institutions to explore WBL to remain competitive and cost-effective. Hence, WBL became an instructional delivery method for the growing number of working adults who sought to earn degrees from universities that provide external programs. Malaysian universities that run WBL programs include Open University Malaysia, Universiti Tun Abdul Razak, and Wawasan Open University [36]. Another two international Malaysian universities also run WBL- Asia e-University and Madinah International University. Two public universities also has WBL programs- Universiti Malaya and Universiti Putra Malaysia.

\section{Web-based Learning in TVET}

TVET has not been excluded from the technology explosion in T\&L. [37] states that e-learning can assist learners in obtaining information. E-learning is a T\&L process that uses electronic network (LAN, WAN or Internet) to deliver content, information and serves as a medium for interaction. [38], has provided examples from electronic media devices used to implement e-learning which are the internet, intranet, satelite, audio-video tapes interactive tv and CD rom. According to [39], e-learning is a combination of electronic technology and educational elements. [40] state that learning using video streaming is a form of electronic learning and can be called as e-learning. There are several technical and vocational higher education institutions that have carried out research on e-learning, which include Universiti Teknologi Malaysia, Universiti Tun Hussein Onn Malaysia, Polytechnics and Comunity Colleges.

\subsection{The Application of Web-based Learning in Public Higher Education}

According to [41], e-learning has been practiced as a mean to diversify existing teaching method. E-learning has enabled 
graduates to communicate directly with educators or among themselves through the internet using services like email, bulletin and discussion/forum available. Rapid ICT development has given an impact to every aspect of live including education [42]. Technical and vocational education is not exempted from the ICT explosion especially in its T\&L process [41]. E-learning in Malaysia has started to grow rapidly and widely in the early 90's. Compared to other countries like the Europe, U.S and Japan, Malaysia is actually a little behind in the concept of e-learning. At that time e-learning was more focused on online distance learning largely offered in university level and private colleges that has cooperation with universities abroad [43]. [44] has conducte a research o $\mathrm{n}$ the perception of learners toward one e-learning application in 1995. The research is aimed at observing the learners' perception toward T\&L conducted through video conference lecturing in Universiti Sains Malaysia. Video conferencing system in Universiti Sains Malaysia has been introduced to engineering students first before science students because engineering students have more exposure to technology than science students. Findings from the research indicates that engineering students have been found to adapt easier to video system than science students and both groups of students have positive attitudes toward the activities in video conferencing system used.

Several researches have been carried out regarding awareness, evaluation and acceptance of e-learning among academician. [45] has said that the awareness toward e-learning is high because the university administration is encouraging academicians to use e-learning systems in their T\&L activities. Meanwhile, Universiti Kebangsaan Malaysia has conducted a research on student readiness in using e-learning platform. [46] has conducted a research on student readiness toward long distance learning. Findings from this research show that students believe internet use can help them in their studies. Almost 64 percent among the internet users will print information they have found on any sites. This clearly proves that distance learners have sufficient readiness toward T\&L materials through the internet [46]. [47] has conducted a research regarding virtual learning (e-learning) entitled "Teaching and Learning Service Through email and Nicenet Website: A Case Study in Tun Hussein Onn Institute of Technology. This research has been conducted to achieve 3 objectives. The first objective is to identify the acceptance of higher education students toward T\&L service through the use of Nicenet website, emails as an alternative to conventional method where students meet lecturers in lecture rooms. The second objective is to identify the different students' perceptions toward using the Nicenet website, emails and conventional method in T\&L. In addition, the third objective is to identify problems faced by undergraduates by using the Nicenet website method, email and conventional method.

Finding from the research indicate that students accept the use of using the Nicenet website in T\&L service as an alternative so that they can conveniently interact with their lecturers compared to the traditional method. Nevertheless, not all basic problems from the conventional method can be solved using the Nicenet web and email method. Yet, explanations given by lecturers are understood easier through Nicenet web and emails because such explanations remain in the students' individual computers. Therefore, using this method, the lecturer can help a big number of students in any given time.

[48] have conducted a research entitled "Technic and Vocational Students' Method in Learning Technical Skills Using (SWEB-Tech) Web". It has been developed to assist learning the skill to setup theodolites among technical and vocational students. [49] state that learning practical skills among engineering students incur high cost and time spent in laboratories is too long. The skill to setup theodolites to take readings and detailed measurements and plot data obtained in measurement is a basic skill in measurement in civil engineering. The uniqueness offered by this website is that it can be accessed by students anytime. The finding suggests that students will learn independently and are able to repeat the page that has provided the information regarding the topic being taught.

[41] have conducted a research regarding the use of e-learning among technical and vocational education students in public higher education institutions in Johor that are UTM and UTHM College. The research has been carried out to identify the undergraduates' performance toward e-learning and obstacles faced in using e-learning. According [50], an individual who has low personal skill toward e-learning will be less confident in the ability to acces e-learning and not efficient in using the skill in daily life. Finding from the UTM and UTHM College undergraduate indicate that they possess high confidence in using e-learning because they are given the accommodation to use computers, there are computer courses and the use of the internet is a common occurrence in T\&L [41]. [51] has conducted a research to observe adult students' perception toward e-learning. This study has been conducted on a group of students undertaking Electrical Engineering Bachelor's Degree program in Unversiti Teknologi Malaysia. The students learn using e-learning method at METEOR Distance Learning Sdn. Bhd. Result from the research are as follow:

i. Students are able to accept the learning prepared by METEOR Distance Learning Sdn.Bhd. because it fulfills the principle needs of virtual learning and adult learning.

ii. The level of e-learning implementation at METEOR Distance Learning Sdn.Bhd. from the perspective of the students, is average and relevant parties need to take action in improving the characteristics and quality of learning.

iii. The learning environment in Peninsula and East Malaysia is at a high level because METEOR Distance Learning Sdn.Bhd. has provided good learning environments on both locations.

iv. The problems faced by adult learners in e-learning (fee cost, learning day, timetable, lecture time and transportation) is at an average level and not so critical.

v. Learning using the e-learning method in METEOR Distance Learning Sdn.Bhd. has a lot of advantages to 
the students however, several weaknesses have also been identified.

vi. A few suggestions have been given to METEOR Distance Learning Sdn.Bhd. Among others are, to hold meetings with lecturers, to prepare notes and modules and to reevaluate the marking scheme to lighten the burden on students.

[43] in his research has concluded that electronic learning or e-learning has provided many benefits and advantages in learning and has helped student academic achievement. Findings from this research also points out that students has always remain positive toward e-learning use. This indicates that students can accept electronic learning as an alternative to obtaining extra materials in the learning process. [42] state that ICT research pattern in teacher education in Malaysia has revealed eleven different concepts. The top four concepts are delivery system, learning environment, learning outcome and instructional method. This can also be seen in the research pattern regarding the use of web-based learning in TVE which started with lecturer delivery method, students' acceptance and the effects and the web-based types used.

[52] in her research about the use of Mobile Learning (M-Learning) for learning purposes among UTHM engineering students has found that students' readiness toward e-learning is at a high level. [53] mentions that mobile communication technology has provided a variety of alternatives and communication convenience for example mobile phones equipped with the function of send and receive emails, short messaging service and multimedia messaging service that comes in the combination of music, images, animations and short videos. M-Learning has been proven to be more effective abroad and according to [54] in their research regarding testing implemented using mobile devices have found that assessments carried out using M-Learning are more effective and efficient because of the time saved compared to tests using pencil and paper. The use of M-Learning can help increase student motivation, improve organizing skills, build a sense of responsibility, encourage collaborative learning and help checking students' performance quicker and more effectively $[55,56]$.

\subsection{Web-based Learning Application in Community Colleges}

According to [57], the general concept of the establishment of community colleges is due to the needs of local community. Community Colleges provide training and education to secondary school leavers before entering the job market or furthering their education to higher levels. In addition, Community Colleges provide the opportunity for local communities to continuously obtain training and skill in order to produce knowledge community. [58] states that the internet in $T \& L$ can be used as a huge resource repository for lecturers and students to explore, find teaching resources and research reference. Through educational websites prepared, local and foreign lecturers and students can benefit from the full extent of the internet facilities. In addition, every content in websites or portals is constantly updated and students can access a huge amount of new contents compared to reference book that are rarely updated.

[57] have structured the use of ICT in Community Colleges' T\&L into two aspects that are the teaching aspect referring to the lecturers' teaching and the learning aspect referring to the students. From the teaching aspect, ICT is used as tools for presenting and demonstrating. Meanwhile, on the learning aspect, ICT is used as tutorial (Expository), exploration (Exploratory), application and communication. Technical lecturers in Ledang Community College uses simulation program in the teaching of engine overhaul and air cooling and conditioning when explaining about the latest technology in cooling and conditioning. This method gives better understanding to students compared to explanations on the whiteboard.

\subsection{Web-based Learning Application in Polytechnic}

[59] has conducted a research on web-based teaching method involving Electric Mechatronic Engineering Diploma students in Tuanku Sultanah Bahiyah Polytechnic in Kulim, Kedah. [46] explains that a website is an integration of graphics, texts and sounds in one display page. [60] states that a website is a page that has a unique and attractive visual presentation and involves background graphics, logos, icons, font sizes, menu buttons and color combinations. [61] states that a website must have a variety of information in the form of texts, graphics, animations, audio and video based on the preference and creativity of the particular website builder. The website used is the website for learning Safety in Robotics Workshop for the Industrial Robotics and Automation subject. The research findings show that students have a positive attitude toward WBL and students' understanding toward safety in robotics workshop subject has been increased. However, there have been some problems with WBL including lecturers' skill, polytechnic students' computer literacy, incomplete infrastructure, time constraint and the location of the polytechnic.[59] have suggested that the Malaysian polytechnic administration to:

i. Increase the lecturers' computer literacy by training and encouraging them to produce innovative and high technology T\&L methods. This is in line with [62] who states that the main purpose for training is to achieve any change in knowledge, behaviour and character that can increase the ability and quality of staff.

ii. Increase the computer literacy level among students by making amendments to the curriculum that has any relationship to computer literacy among students.[59] explains that the teaching of computer literacy skill must focus on T\&L environment that:

i. Encourages students to search, access, use and evaluate information using multimedia technology,

ii. Encourages students to use information network like the internet.

iii. Provide virtual learning.

iv. Encourages collaborative and cooperative learning.

v. Inculcates student development toward analytical and creative thinking and able to make decision to solve 
problems.

vi. Encourages independent learning

vii. Creates self-paced learning environments

iii.Improve Polytechnic computer infrastructure by supplying lecturers access to faster internet connection. Therefore, lecturers can can build websites that can be accessed by students through facilities provided outside campus.

iv. Increase the administrators' commitment in ensuring the lecturers' skill improve at par with the rapid technology development.

v. Repel negative elements through advice.

\section{Advantages and Disadvantages of Web-based Learning in TVET}

\author{
Advantages of Web-based Learning \\ Among the advantages of WBL are: \\ Distance Learning
}

The web is a very good tool to convey T\&L online and in this context, distance learning in TVET. Most educational websites that are developed for T\&L purposes in this country are based on tutorial approach [63]. Teaching materials that uses the tutorial approach normally have an organized structure that can be easily followed by students. This for of structure is highly suitable for distance learning. Web-based environment has the potential to offer more advantages to learners to improve the learning process compared to the traditional learning package in classrooms [64]. In addition, the advantage of the web lies on the use of hypertext and hypermedia systems and also synchronous communication tool like the Internet Relay Chat and asynchronous communication tool like emails and online discussion [65]. This method enables individuals to participate in open and independent learning sessions at their own pace without following timetables or attending designated classes [66]. Technical and vocational education are not left to apply the use of the web in distance learning.

Student Centered Learning.

Students have been found to have difficulty in concentrating and showing interest in classroom T\&L especially the ones that are only teacher centered [67]. WBL is able to support learning based on behaviourism to change to constructivism [68]. Constructivism learning involves the students to construct their own knowledge and apply a variety of skills and make logical synthesis. Nowadays, there are many websites that exist and have different functions like conveying information, teaching and handling various activities [65]. In technical and vocational education, for example in community colleges, work-based learning practice requires students to explore through the website. In order to build multimedia applications using cognitive application, the T\&L process must include students' active involvement [69]. This is when students build their own knowledge or concept actively based on previous knowledge. This is because it is the students who are going to interact with the web being developed and obtain understanding regarding the content and event [70].

\section{Instilling High Order Thinking Skills}

WBL gives the chance for students to acquire higher thinking strategies that encourage divergent thinking with the existence of guides from different perspectives [71]. A constructivist WBL, where students are encouraged to state their individual opinions and ideas, conducts reflections, explore diverse knowledge resource and identify the strengths and inclinations of arguments, makes the core to nurture higher order thinking skills [72]. This is supported by [73] who have found that the web component gives the chance to students to interact asynchronously between each other giving highly positive effect on learning and higher order thinking skills. The use of websites is able to guide and form students' minds so that they will become more creative and understand the knowledge concept more effectively especially in technical and vocational education [70].

More convenient for Students and Saves Time.

Students can also use the web to find information and the latest development regarding their studies quickly with great ease. For example, in UTHM andragogy approach requires students to work in groups to find information using web based learning. This is because the aim of adults' education is broad involving their determination to develop skills, enriching knowledge as well as improving their qualification and professionalism [74]. Lecture notes or information related to $\mathrm{T} \& \mathrm{~L}$ and even the $\mathrm{T} \& \mathrm{~L}$ process itself can be distributed and obtained through the web where every students can access them at the same time. Hence, it will make it more convenient and save the students a lot of time in retrieving any information. According to [75], the importance of weblog to students is that they can communicate about current issue or the latest information directly, preparing a portal for students to use, making it easier for students to hand in assignments and also, making it easier for students to see comments regarding assignments or subjects being discussed. According to [76] the use of e-learning has given the students freedom to follow the learning process. In addition, e-learning is an Information and Communication Technology (ICT) to facilitate learning which was also applied in the field of TVET.

\section{Cost Reduction}

Some of the courses offered in the field of training and skills incur high cost. Therefore, technology assistance can help reduce the cost of acquiring the needed skills. There are four main reasons that have caused higher education to use technology [77]. This include improving the quality of learning, improving the access to education and training, reducing the cost of education and improving education cost effectiveness. WBL is useful in replacing real situation T\&L that require high cost and difficult to manage [78]. Using web based learning are cost reduction, for example, in medicine, manufacturing, technical and vocational education and military. For a learning process involving risky real simulation, the use of technology can make it easier for students, saves time and reduce cost. For example, surgical simulation for 
medical students, flight simulation and TVET.

Increase Motivation and Access

Aspects that include motivation and emotion can affect executive control in increasing attention and also to arrange cognitive strategies, facilitating planning and use of knowledge Che Wan [79]. Teachers' experience in applying the web in teaching has developed a sense of excitement and interest among students toward the teaching in technical and vocational education [80]. Through the application of information technology, the T\&L environment has become more interesting and has a high potential in increasing $T \& L$ quality [81]. Research carried out [82] has found that interactive websites can continuously attract students' attention to the learning session. 'Interactive' is closely related to respond or individual control [83]. Individuals who have high self-motivation are able to strive toward excellent performance. Web learning that uses constructivism approach has been found to be effective in improving students' academic performance [84]. Effective learning styles among students also depend largely on motivation, interest and teaching style introduced by the teacher or lecturer in polytechnics, community colleges and universities. Effective learning is fun learning [85]. T\&L approach based on the web is user friendly and can attract students' interest because the web fulfills the learning resource needs in TVET [86].

\section{Weaknesses in WBL}

Among the weaknesses of WBL are:

\section{Technological Obstacles}

Access to computer and technology equipment and also the internet might be a problem to students especially those who live in rural areas. There are a number of polytechnics and community colleges are located in rural areas. Weak internet access has stopped students from accessing every display in a website. Graphics and videos are among those displays. This has indirectly limited access to learning content being delivered. Technological obstacles include extremely slow internet network, e-learning access and equipment preparation, software and computer service or repair [76]. Technological obstacles include technology quality, lack of technical skill and support, technology use comfort, technology change and "log-in" problems [87]. To complete all this technology device needs, a high cost is required. Students not only need support but also need places to learn uninterrupted for WBL [88]. This clearly indicate that a computer laboratory or a special space needs to be built to accommodate students' comfort which will definitely incur high cost. High cost will be incurred in the procurement of devices, software, computer service and repair [76]. The main problem faced by students while using e-learning in universities is the lack of internet facility [89]. Having internet-connected computers influences students' frequency and ability to access learning websites [90]. The ratio of the number of computers with the number of students still on low level in University Technology Malaysia and University Tun Hussein Onn Malaysia [76].

\section{Lack of Moral Value Implementation.}

Most website that have been built or software being developed lack moral value implementation. Without having a teacher who acts as a facilitator, students who uses WBL have failed to master effective learning methods like simple note taking [91]. Most software being developed in the market do not have the equilibrium between entertainment and education This has lead to problems in character, behaviour, performance and achievement among students nowadays [92]. The young generation is easier and quicker to be influenced by multimedia contents in the process of developing their character [93]. This statement is in line with [94] who has discussed that the development of students' character and attitude nowadays is more influenced by software based on information technology parallel with the current global development.

\section{Conclusions}

In conclusion, in the education process, guidance, support and teachings provided at home is the basic for students to develop and advance. Among the factors that are needed to enable the country to achieve the aim of creating an advanced nation and able to compete in globalization are positive attitude and self-confidence toward new technology in TVET. Careful preparation and positive acceptance must exist in every individual because the use of computer and internet is thought to be able to assist in creating a sustainable learning environment that stresses three important elements that are self-paced and self-directed.

Education has increased with the use of WBL [95], [96], [97], [98]. Rapidly advancing technology is effective in every field of students' lives. Due to the age of technology in which they were born, students have more positive attitudes towards technology compared to the previous generation before them. Therefore, web-based materials prepared especially in subjects that the students have comprehension problems, will facilitate student learning. Use of additional instructional materials by the teacher during the learning-teaching process will help increase students' cognitive and affective qualities and unexpected in-class performances will be prevented. Nowadays, it has been focused on understanding learning process instead of what students need to learn. It has been realized that individuals who know how to reach information and use the information instead of memorizing should be trained. At this point, while designing effective learning environments, Ausubel's meaningful learning theory helps educators [99]. This theory is based on the idea that reasoning capacity of a person is mainly connected with the person's concepted framework in a specific domain of knowledge [100].

WBL can be a satisfactory experience for those who are faced with the challenge of accessing continuing education. Adapting to web learning however, presents a number of challenges [101]. According to [102] meaningful learning is forming viable relationships between ideas, concepts and information. WBL system is a system that usually refers to e-learning [103], also known as online learning [104]. A WBL system is defined as a learning method where instructional content and interaction between instructors and students are 
processed via web-enabling technologies through the Internet [105]. WBL systems served as a platform to facilitate teaching and learning and to provide new approaches for conducting classes and delivering course materials [104].

Web-based learning has also been known to offer flexibility and greater motivation of students to excel [106]. [107] In press 2005, found in a study on modeling tools for the classroom that modeling impacts students' understanding of concepts being taught and that pre/post assessments should be subject specific for analyzing the improved student learning. With the existence of high technology equipment, we are able to transform learning methodology to create a wide learning community, to connect humans in real-time on in the virtual world, to prepare the needed expertise and in turn, support life-long learning [108] WBL requires more time and bigger resource commitment compared to conventional learning [97]. [22] explains that web application in T\&L is focused toward the betterment of knowledge and performance because knowledge in this era is no longer given but explored [109].

The WBL has become a feasible tool for facilitating education for a wide spectrum of participants using a variety of technologies however it must uses and provides adequate fund to ensure electronic way of learning to cope up the demand needed for TVET. Despite technological limitations, WBL might be successfully implemented and possesses the capabilities for overcoming many problems associated with traditional classroom based learning framework. Considering the rapid expansion of the usage of mobile communication devices in the country, development of technology and reduction in cost, well designed WBL framework is expected to contribute significantly in educational development and thereby having a long term effect on TVET. The initiative can further be enhanced by exploring newer technologies like $\mathrm{m}$-Learning to be incorporated into the program. In a time of continuous economic, social and technological change, skills and knowledge become quickly out of date.

\section{References}

[1] A. H. Hajar, Penggunaan Laman Web Pendidikan Dalam pengajaran Dan Pembelajaran Di Kalangan guru-guru Di Empat Buah Sekolah Bestari di Negeri Johor. Sarjana Muda. Universiti Teknologi Malaysia, Skudai, 2010.

[2] J. Rozinah, Internet dalam Pendidikan. USM Pulau Pinang: Penerbit Universiti Sains Malaysia, 2007.

[3] H. I.Arif, dan R. Norsiati, Aplikasi Teknologi Maklumat Dan Komunikasi Dalam Pengajaran Dan Pembelajaran: Perspektif Mata Pelajaran Kimia Spm. Fakulti Pendidikan, Universiti Kebangsaan Malaysia, Bangi, 2011. R.

[4] H. I. Arif, M., Rosnaini, S. Paridon, Y. Zainuddin, Pembelajaran berasaskan Web dalam kalangan guru-guru Bahasa Malaysia berasaskan pembelajaran berasaskan permainan. 1st International Malaysian Educational Technology Convention., 2011, pp 1042-1055.
[5] C. Brown, M. Collin. and R. Drgged, Computer based curriculum developments tools for teachers. New York. Teachers College Press, 1994.

[6] A. Muhaimin, Pembangunan Modul Elektonik Berasaskan Laman Web Belajar Mengenai Micromedia Fireworks mx. Kertas Projek Sarjana PendidikanUniversiti Kebangsaan Malaysia, 2004.

[7] R. Rasimah, Pembangunan Laman web Interaktif Asas Komunikasi Bahasa Jepun. Tesis Sarjana. Universiti Kebangsaan Malaysia, 2007.

[8] J. Jamilah Jamaluddin, Reka bentuk dan Pembangunan Bahan Pengajaran dan Pembelajaran Berasaskan web (webQuest) Bagi Mata Pelajaran ICT TajukComputer Security, 2010.

[9] L. A. Petrides, Web-based technologies for distributed (or distance) learning: Creating learning-centered educational experiences in the higher education classroom. International Journal of Instructional Media, 2002, 29(1), pp 69-77.

[10] S. Vonderwell, An examination of asynchronous communication experiences and perspectives of students in an online course: A case study. Internet and Higher Education, 6, 2003, pp 77-90.

[11] J.K Gallini and D. Barro, Participants' perceptions of web-infused environments: A survey of teaching beliefs, learning approaches, and communication. Journal of Research on Technology in Education 34(2), pp 139-156, 2002.

[12] M. K. Tallent-Runnels, A. K. Thomas, W. Y. Lan, S. Cooper, T. C. Ahern, S. M. Shaw, and X. Liu. Teaching courses online: A review of the research. Review of Educational Research 76(1), 2006, pp 93-135.

[13] P. Mishra, The seven trans-disciplinary habits of mind: Extending the tpack framework towards 21 stcentury learning. Educational Technology, 2009, 11(2), pp 22-28.

[14] H. Yusup, Penggunaan e-Pembelajaran dalam pengajaran dan pembelajaran yang berkesan. Konvensyen Kebangsaan Pendidikan Guru (KKPG) 2012.

[15] H. Zolkepeli, Z. Effandi, M. Zurina and S. Huki, Persepsi UKM terhadap Pembelajaran on-line. Prosiding Konvensyen Pendidikan kali ke 14, 2001 pp 247-257.

[16] M. N. Norazah and E. M. Amin. Pengintegrasian ICT dalam Pendidikan Penyelidikan, Amalan dan Aplikasi. Shah Alam: Penerbit Karisma Publications, 2008.

[17] M. T. Romano, Empowering teachers with technology: Making it happen. Scarecrow Press, Oxford, 2003.

[18] S. Mahimun, Analisa Laman Web Pendidikan Islam: Penggunaannya Sebagai Bahan Bantu Mengajar. Laporan Penyelidikan Kajian Bebas. Fakulti Pendidikan: UKM, 2007.

[19] A. Relan and B.B Gillani, Web-based instruction and traditional classroom: Similarities and differences. In B. H. Khan (Ed.), Web-based instruction. Englewood Cliffs, NJ: Educational Technology Publications, 1997.

[20] B. H Khan, Web- Based Instruction. Englewood Cliffs, NJ: Educational Technology Publications, 1999.

[21] K. Abtar, Integrating library resources into a web-based learning. Jurnal BTP, 1999, pp, 25-34. 
[22] M. J. Rosenberg, E-Learning: Strategies for Delivering Knowledge in the Digital Age. McGraw-Hill, 2003.

[23] K. Zahiah and A. A. Razaq, E-Pembelajaran: Evolusi Internet dalam Pembelajaran Sepanjang Hayat: UKM, 2009.

[24] C. Y Fook and G. K Sidhu, Integrating information and Communication Technology (ICT) into university teaching and learning: A case study. Asean Journal University of Education, 2007, pp 71-94

[25] K. V. Deore,. The Educational Advantages of Using Internet. International Educational E-Journal, \{Quarterly\}, ISSN 2277-2456, Volume-I, Issue-II, Jan-Feb-Mar 2012.

[26] B. H Khan, Web-Based Instruction. New Jersey, Penn: Educational Technology Publications, 1997.

[27] P. G Geisert and M. K Futrell, Teachers, Computers, and Curriculum Microcomputers in the Classroom Third Edition. United States of America. Allyn \& Bacon, 2000.

[28] G. Ahamer, "Game idea for a web-based game on global change", working paper for the Unigame project, FH Joanneum, Graz, 29 November, 2002.

[29] H. Geirlinger, "Re-use of current teaching resources at a dual-mode university", Campus-Wide Information Systems, Vol. 18 No. 3, 2001, pp. 120-4.

[30] G. Ahamer, Negotiate your future: Web based role-play. Campus-Wide Information Systems, 21(1), 2004, pp. 35-58.

[31] R. Garris, R and R. Ahlers, A game-based training model: Development, application, and evaluation. Paper presented at the 2001 Interservice/Industry Training, Simulation, and Education Conference, Orlando, FL, 2001.

[32] C. Perrotta., G. Featherstone, H. Aston, E. Houghton, Game-based Learning: Latest Evidence and Future Directions, Slough, NFER, 2013.

[33] E. Klopfer, S. Osterweil, and K. Salen, Moving learning games forward. Cambridge, MA: The Education Arcade, 2010.

[34] J. Kinsey, Ten Family-friendly Apps for FCS Educators. Journal of Family and Consumer Sciences, 2011, 103(2): 57.

[35] C. P Wai, L. T Kevin and G. R David, A study of Web-based learning (WBL) environment in Malaysia. The International Journal of Educational Management Volume 18, Number 6, 2006, pp. 374-385.

[36] Kementerian Pengajian Tinggi Malaysia, Pelan strategik pengajian tinggi negara: melangkau tahun 2020. Putrajaya: Kementerian Pengajian Tinggi Malaysia, 2008.

[37] Rader, M \& Wilhelm, W. Needed research in business education ( $6^{\text {th }}$ ed.). Little Rock, Ar: Deltha Pi Epsilon. 2001.

[38] Kaplan-Leiserson, E., We-Learning: Social Software and E-Learning, Learning Circuits, American Association for Training and Development, 15 December 2003.

[39] Rahimi Md. Saad, Wan Nordin Wan Abdullah and Zawawi Ismail, Web-Based Teaching and Learning Arabic, MPBL Educational Research Seminar 2005, Kuching, 15th-16th September 2005.

[40] Siti Faizzatul Aqmal M.M \& Razali, H. Pengajaran dan pembaelajaran berasaskan 'Streaming Video' bagi meningkatkan tahap kefahaman pelajar Abad ke-21.
Persidangan Kebangsaan Penyelidikan dan Inovasi dalam Pendidikan dan Latihan Teknik dan Vokasional. CIETVT 2011. $\begin{array}{llll}\text { Retrived } & 5 & \text { November } & 2015\end{array}$ http://eprints.uthm.edu.my/2572/1/Pengajaran_dan_Pembelaja ran_berasaskan_streaming_video.pdf

[41] Muhammad Sukri Saud, Mohd Anuar Abdul Rahman, \& Ting K.S. Kajian mengenai penggunaan e-pembelajaran dikalangan pelajar jurusan pendidikan teknikal dan vokasional di institut pengajian tinggi awam (IPTA) negeri Johor. Proceedings of the1st International malaysian Educational Technology Convention (pp 1123-1127). Kuala Lumpur: META. 2007.

[42] Irfan Naufal U \& Nurullizam J. Trends of ICT research in teacher education: An Analiysis of the Malaysian Instructional Technology Proceedings. Asia Pacific journal of Educators and Education, Vol. 26, No. 1, 1-14, 2011. Retrived 5 November 2015 at

http://apjee.usm.my/apjee_26.1.2011/26.1.2011_1-14.pdf

[43] Balwi, M. K., M. A. Abd Hamid, M. F. bin Othman, M. S. Bakri, dan A. M. Junoh. $A$ Study on the Readiness of University Students To Use E-Learning As A Learning Tool: Case Study of University Teknologi Malaysia, Skudai, Johor. Report Research For Research Management Centre (RMC) Universiti Teknologi Malaysia, Skudai. 2004.

[44] Md. Noor Salleh. "Telecommunication Applicants for Distance Education Malaysia”. Innotech Journal. Julai - Disember. 55, 1996.

[45] Rubiah, O. dan Jamilah, A.Kesedaran, Penilaian dan Penerimaan e-Pembelajaran dalam kalangan Ahli Akademik. Jurnal Pendidikan Malaysia 34(1) (2009): 155-172.2009.

[46] Zolkepli Haron, Effandi Zakaria, Zurina Mahadi \& Hukil Sino. Persepsi pelajar PJJ UKM terhadap pembelajaran secara online. Pembentangan Kertas kerja Konvensyen Persatuan Teknologi Pendidikan Malaysia kali ke 14. Hotel Goldcourse, Kelang. 11 -14 September. 2001.

[47] Esa, A., A. Suradin, dan K, A, Suhaimy.. Perkhidmatan Pengajaran dan Pembelajaran Menerusi laman Web 'Nicenet' dan E-mel: Kajian Kes. Dalam Prosiding Konvensyen Pendidikan UTM, 2000. Skudai: Penerbit Universiti Teknologi Malaysia: Kertas Kerja. 175-194.

[48] Z, Tasir, and Z, Yasak Cara pelajar pendidikan teknik dan vokasional mempelajari kemahiran teknikal dengan menggunakan laman web (SWEB-Tech). In: Seminar TVE06, 09-10 Desember 2006, Hotel Sofitel Palm Resort Senai Johor. (Unpublished) retrived at 6 November 2015 at http://eprints.utm.my/2277/1/Zaidatun_Tasir.pdf

[49] Ferris, T. L. J. \& S. M. Aziz. A Psychomotor Skills Extension to Bloom's Taxonomy of Education Objectives for Engineering Education. INEER Conference for Engineering Education and Research. Taiwan, 1-5 March 2005. http://www.unisa.edu.au/seec/pubs/05papers/Ferris_T_iceer20 05_03-002.pdf

[50] Matthew S. Eastin and Robert LaRose. Internet Self-Efficacy and the Psychology of the Digital Divide. Journal of Computer-Mediated Communication, Article first published $\begin{array}{lllll}\text { online: } & 23 & \text { JUN } & 2006 & \text { DOI: }\end{array}$ 10.1111/j.1083-6101.2000.tb00110.x

[51] Chong S. K. @ K. Chong. Penilaian Persepsi pelajar Dewasa Terhadap E-learning: Satu Kajian Di Meteor Distance Learning Sdn.Bhd. Universiti Teknologi Malaysia, Skudai. Latihan Ilmiah. Fakulti Pengurusan dan Pembangunan Sumber Manusia. UTM, Skudai, Johor. 2002. 
[52] Norliza A.R. Penggunaan Mobile Learning (m-Learning) untuk tujuan pembelajaran dalam kalangan pelajar kejuruteraan UTHM, Tesis Sarjana pendidikan Teknik dan Vokasional,.2013 $\begin{array}{llll}\text { Retrived } & 6 & \text { November } & 2015\end{array}$ http://eprints.uthm.edu.my/5372/1/NORLIZA_BINTI_A.RAH IM.pdf

[53] Donald, J.L. Wireless Messaging Demystified: SMS, EMS, MMS, IM, and Others. United States: McGraw-Hill Professional. 2003.

[54] Triantafillou, E., Georgiadou, E., Economides A. A. He Design and Evaluation of a Computeriaed Adaptive Test on Mobile Devices. Science Direct (pp.1319- 1330). Elservier. 2006.

[55] Savill-Smith, C., \& Kent, P.. The Use of Palmtop Computers for Learning: A Review of The Literature, London, UK: Learning and Skill Development Agency.2003.

[56] Hamdan, A., Din, R. \& Abdul Manaf, S. Z., Penerimaam M-Pembelajaran dalam Sistem Pendidikan di Malaysia. The Unified Theory of Acceptance and Use of Technology (UTAUT): Satu Analisis Literatur. UKM, Malaysia 1st International Conference on Mobil Learning, Applications, and services (mobilcase2012).

[57] Amier Hafizun AR, Noorsafuan C.N; \& Norazila A, Penggunaan ICT dalam konteks pengajaran dan pembelajaran TVET di Kolej Komuniti Ledang Johor. 2013 Retrived 5 November 2015 https://www.academia.edu/6893294/PENGGUNAAN ICT D ALAM_KONTEKS_PENGAJARAN_DAN_PEMBELAJAR AN_TVET_DI_KOLEEJ_KOMUNITI_LEDĀNG_JOHOR

[58] Zalina Yahaya.. IT dan Komputer: Nadi Sekolah Bestari. Utusan Malaysia.2002.

[59] Y, Zurina, M, Baharom, E, Ahmad and S, Shahrizal. Kaedah pengajaran berasaskan laman web terhadap pelajar Diploma Kejuruteraan Elektrik Mekatronik di politeknik. In: Persidangan Kebangsaan Pendidikan Sains dan Teknologi, 26-27 Oktober 2009, Universiti Tun Hussein Onn Malaysia.

[60] Ahmad Zaharim Abdul Aziz, Menguasai Internet. Kuala Lumpur: Pustaka Cipta Sdn Bhd.1999.

[61] Mohd Arif Ismail \& Mohd Jasmy Abd Rahman., Pembinaan laman web untuk pengajaran fokus terhadap kursus GE2123: Teknologi dan inovasi dalam pendidikan. Prosiding Seminar Pendidikan Kebangsaan 2000. Hotel Equatorial Bangi. 14-15 November 2000.

[62] Barry, Cushway. Human Resource Management. London: Kogan Page Limited. 1994.

[63] Irfan Naufal Umar. Penilaian laman web pendidikan di Malaysia: Satu tinjauan, Dalam Konvension Teknologi Pendidikan ke 16, 13-16 Jun 2003, Melaka: Persatuan Teknologi Pendidikan Malaysia, 326-328.

[64] Khan, B. H. Web-Based Instruction: What is it and why is it? In B. H. Khan (Ed). Web Based Instruction. pp. 5-18. Englewood Cliffs, NJ: Educational Technology Publications. 1999.

[65] Tina Lim Swee Kim, Pembelajaran berasaskan web: Kesan pendekatan konstruktivis berbanding pendekatan langsung. Maktab Perguruan Ipoh, Perak.2002.

[66] Kassim, Z. dan Abdul Razaq. E-Pembelajaran: Evolosi Internet dalam Pembelajaran Sepanjang Hayat: UKM. 2009.
[67] Tukiran, N., Mohd @ Ariffin, J. \& Mohammad Rozi, S. H. Teori Kecerdasan Pelbagai untuk Meningkatkan Penglibatan Aktif Pelajar Di Dalam Kelas. Guru Pelatih. DPLI: UKM. 2010.

[68] Jonassen, D. H. Activity theory as a framework for designing constructivist learning environment. ETR\&D Vol.47, No. 1. pp 61-79. 1999.

[69] Baharuddin Sidki \& Nik Rahimi Nik Yusoff. Cabaran Penggunaan ICT dalam P\&P Pendidikan Islam. Dalam Norazah Mohd. Nordin \& Mohamed Amin Embi (pynt). Pengintegrasian ICT dalam Pendidikan, Amalan dan Aplikasi. Shah Alam: Karisma Publication. Sdn. Bhd. 2008.

[70] Hussin, N., Mohamad Sattar Rasul \& Abd. Rauf, R. Penggunaan laman web sebagai transformasi dalam pengajaran dan pembelajaranPendidikan Islam. Universiti Kebangsaan Malaysia, Selangor. 2013.

[71] Hill, J. R., Distance learning environments via the World Wide Web. In B. H. Khan (Ed). Web Based Instruction. pp. 75-80. Englewood Cliffs, NJ: Educational Technology Publications. 1997.

[72] Bonk, C. J. dan Reynolds, T. H., Learning centered Web Instruction for higher order thinking, teamwork, and apprenticeship. In B. H. Khan (Ed). Web Based Instruction. pp. 167-178. Englewood Cliffs, NJ: Educational Technology Publications. 1997.

[73] Sanders, W. D., dan Morrison-shetlar, A. I, Students Attitudes towards web enhanced instruction in an introductory biology course. Journal of Research on Computing in Education, 2001, 33(3), 251-262.

[74] S. Ashari, I. Sapon, M.H. Hisyam \& M. Ahmad Rizal, Learning Technique among Adult Students in Higher Learning Institutions, Ministry of Higher Education, Journal of studies in Education ISSN 2162-6952, V01. 2, No.4, 174-186, 2012.

[75] Richardson, M. \& Domingos, P., Markov Logic Networks. Department of Computer Science and Engineering, University of Washington, Seattle, WA 98195-250, U. S. A. 2006.

[76] Mohammad Sukri Saud, Mohd Anuar Abdul Rahman \& Ting Kung Shiung.. Kajian Mengenai Penggunaan E-Pembelajaran (E-Learning) Di Kalangan Pelajar Jurusan Pendidikan Teknikal dan Vokasional Di Institut Pengajian Tinggi (IPTA) Negeri Johor. Universiti Teknologi Malaysia, Johor. 2010.

[77] Bates, A. W., Restructuring the University for Technological Change. Paper presented at The Carnegie Foundation for the Advancement of Teaching, London, England. 1997.

[78] Harun, J. \& Tasir, Z., Asas multimedia dan aplikasinya dalam pendidikan. Bentong: PTS Publication, 2003.

[79] Tennyson, R. D., dan Nielsen, M., Complexity theory: Inclusion of the affective domain in an interactive learning model for instructional design. Educational Technology. 1998, $38(6), 7-12$.

[80] Che Wan, C. R. I., Penggunaan Laman Web dalam Kalangan Guru Pendidikan Islam di Daerah Seremban. Tesis Sarjana Pendidikan: UKM, 2007.

[81] Ahmad, S. F dan Ab. Halim Tamuri.. Persersi Guru Terhadap Penggunaan Bahan Bantu Mengajar Berasaskan Teknologi Multimedia dalam Pengajaran j-Qaf. Journal of Islamic and Arabic Education, 2010, 2(2), 53-64. 
[82] Mohd. Sadri, Z., Pembangunan Laman Web Topik Rukun Haji dan Umrah Tingkatan 4 Berdasarkan Teori Konstruktivisme. Tesis Sarjana Muda: UTM. 2010.

[83] Mikovec, A. E. \& Dake, D. M., Tying Theory To Practice: Cognitive Aspects of Computer in the Design Process. ERIC, 1995.

[84] Bills, C. G., Effects of structure and interactivity on Internet-based instruction. (ERIC Document Reproduction Service No. ED 416317). 1997.

[85] Dick, W. dan Reiser, Robert A., Planning Effective Instruction, USA: Allyn and Bacon. 1989.

[86] Saunders, G., Integrating information and communication technology (ICT) into a face-to-face undergraduate course. 2003. Dicapai pada 23 Oktober 2015 dari http://www.elearningeuropa

[87] Schilke, R.A., Acase study of attriction in web-based instruction for adults: Updating Garland's model of barriers to persistence in distance educational, Doctoral dissertation, Northem Illionois University. 2001.

[88] Pollard, E., \& Hillage, J. (Eds)., Exploring e-learning. The Institute for Emploment Studies. Report No. 376. Brighton: UKM. 2001.

[89] Mohd. Koharuddin et. Al, Kesediaan pelajarUniversiti Malaysia menggunakan E-Pembelajaran sebagai satu alat pembelajaran. Satu kajian kes di Universiti Teknologi Malaysia, UTM di Skudai, Johor. 2003.

[90] O'Connor, C., Sceiford, E., Wang, G., Fourcar, Scocki, D., \& Griffin, O., Departure, abandonment, and droupout of e-learning: Dilemma and Solutions. 2003. Retrieved November 6, 2015, from www.masie.com.

[91] Mohd. Jasmy Abd. Rahman, Mohd. Arif Ismail and Norsiati Razali., Tahap kesediaan penggunaan perisian kursus di kalangan guru Sains dan Matematik. Prosiding Konvensyen Teknologi Pendidikan ke 16, 372-380.2003.

[92] Abdul Majid. L, Wan Nasyrudin Wan Abdullah, Ahmad Zakhi. N. H, Penerapan nilai murni dan pembentukan jati diri kanak-kanak prasekolah melalui penggunaan multimedia. Fakulti Pengajian Islam, Universiti Kebangsaan Malaysia., 012 .

[93] Abdul Rawi. N, Pembangunan perisian kursus multimedia untuk belajar membaca: satu pendekatan hybrid (HALR). Tesis Sarjana, Fakulti Teknologi dan Sains Maklumat, Universiti Kebangsaan Malaysia, 2004.

[94] Hamid Ahmad Tahir, Ensiklopedia Pendidikan Anak Cemerlang. Terj. H. Abdullah Tsani. Kuala Lumpur: Jasmin Enterprise. 2009.

[95] J. T. DiPiro. The Virtual University - higher education 'on-line', American Journal of Pharmaceutical Education, 63 (2), 170-174. 1999
[96] G. Joyes. An evaluation model for supporting higher education lecturers in the integration of new learning technologies, Educational Technology \& Society, 3(4), 1-14, 2000.

[97] C. Menaught \& P. Kennedy. Staff development at RMIT: Bottom up work serviced by top down investment and policy, In: Squires, D. Et Al (2000) The changing face of learning technology, Cardiff: University Of Wales, 2000.

[98] C. Spratt, S. Palmer, \& J. Coldwell. Using technologies in teaching: An initiative in academic staff development, Educational Technology \& Society, 3 (3), 455-461, 2000.

[99] J. X. Hao, R. C. Kwok, R. Y. Lau, \& A. Y. Yu, Predicting problem solving performance with concept maps: An Iinformation theoretic approach. Decision Support Systems, 48, 613-621, 2010.

[100] S. L. Bretz. Novak's theory of education: Human constructivism and meaningful learning. Journal of Chemical Education, 78, 1107-1116, 2001.

[101] Atack et. al. A descriptive study of registered nurses' experiences with web-based learning. Journal of Advanced Nursing. Nov2002, Vol. 40 Issue 4, p 457-465. 9p, 2002.

[102] K. A. Williams, \& A. M. Cavallo. Relationships between reasoning ability, meaningful learning and students' understanding of physics concepts. Journal of College Science Teaching, 24 (5), 311-314, 1995.

[103] A. Gunasekaran, R. D. McNeil, \& D. Shaul. E-learning: research and applications. Industrial and Commercial Training, 34(2), 44-53, 2002.

[104] W. T. Wang, \& C. C. Wang. An empirical study of instructor adoption of web-based learning systems. Computers \& Education, 53, 2009.

[105] Y. C. Lee. An empirical investigation into factors influencing the adoption of an e-learning system. Online Information Review, 30(5), 517-541, 2006.

[106] K.L. St. Clair. A case against compulsory class attendance policies in higher education. Innovations in Higher Education. 23: 171-180, 2000 .

[107] R. T. Mohtar, J. Zhai, B. Choi, Engel, and J. Fast. Evaluation of environmental modeling tools for classroom learning. In Press, 2005.

[108] M. Sharple. Big Issues in Mobile Learning. Report of a workshop by Kaleidoscope Network of Excellence Mobile Learning Initiative. Nottingham: The University of Nottingham, 2007.

[109] M. A. Ismail \& N. Razali @ M. Ghazali Aplikasi Teknologi Maklumat Dan Komunikasi Dalam Pengajaran Dan Pembelajaran: Perspektif Mata Pelajaran Kimia Spm. Fakulti Pendidikan, Universiti Kebangsaan Malaysia, Bangi, SM Sains Sultan Hj. Ahmad Shah, Kuantan, 2004. 